\title{
The role of women in the management of Family Hope Program fund in Surabaya
}

\section{Peran perempuan dalam pengelolaan dana Program Keluarga Harapan di Surabaya}

\author{
Marhaeni Mega Wijayanti ${ }^{1}$, Henny Rosalinda ${ }^{2}$ \\ ${ }^{1}$ Department of Sociology, Faculty of Social and Political Sciences, Universitas Airlangga \\ Surabaya, 60286, East Java Province, Indonesia \\ ${ }^{2}$ University of Portsmouth, United Kingdom \\ University House, Winston Churcill Ave, Portsmouth PO1 2UP, Great Britain \\ E-mail of corresponding author: marhaeni.mega@gmail.com
}

\begin{abstract}
This study examines the role of women in the utilization and management of the Family Hope Program fund and describes the process of gender relations constructed in beneficiary families in Surabaya. This qualitative study has two objectives, namely: (1) identifying the role of women in the utilization and management of Family Hope Program funds in Surabaya; and (2) describing the process of gender relations constructed in the beneficiary families. The results indicate that the role of women in managing Family Hope Program funds in Surabaya remains stagnant. Women benefiting from the fund plays a dual role of working in formal and informal sectors and carrying out domestic functions such as caring for babies, cooking, and the likes. These women do not carry out the role in managing the Family Hope Program fund as they are supposed to, such as managing finances and planning needs and spending. This indicates that men still dominate the role of determining the amount of allocation, whereas women are only executors. In addition, the Family Hope Program still cannot restructure the existing gender relations among the people of Surabaya. The program also does not change the pattern of gender relations in decision making in the household. This can be seen from family planning participation. Women benefiting from the fund are reluctant to use family planning contraception due to the husband's prohibition.
\end{abstract}

Keywords: role; women; fund management; Family Hope Program; urban

\begin{abstract}
Abstrak
Studi ini mengkaji tentang peran perempuan dalam penggunaaan dan pengelolaan dana Program Keluarga Harapan serta mendeskripsikan proses relasi gender yang terbentuk pada keluarga penerima Program Keluarga Harapan di Kota Surabaya. Penelitian ini memiliki dua tujuan yaitu mengidentifikasi peran perempuan dalam penggunaaan dan pengelolaan dana Program Keluarga Harapan di Kota Surabaya dan mendeskripsikan proses relasi gender yang terbentuk pada keluarga penerima Program Keluarga Harapan di Kota Surabaya. Metode yang digunakan dalam penelitian ini adalah metode kualitatif. Hasil dari studi ini menunjukkan bahwa peran perempuan dalam pengelolaan dana Program Keluarga Harapan di Kota Surabaya tetap stagnan. Perempuan penerima manfaat Program Keluarga Harapan juga memainkan peran ganda. Selain harus melakukan pekerjaan di sektor formal maupun informal, perempuan juga menjalankan fungsi domestik seperti merawat bayi, memasak, dan sebagainya. Peran perempuan dalam pengelolaan dana Program Keluarga Harapan tidak melakukan peran yang semestinya, yakni mengelola keuangan, merencanakan kebutuhan dan pengeluran. Artinya laki-laki masih mendominasi peran penentuan besaran alokasi, sedangkan perempuan hanya eksekutor. Selain itu, kehadiran Program Keluarga Harapan tidak mampu mengubah struktur relasi gender yang sudah ada di dalam masyarakat Kota Surabaya Program Keluraga Harapan juga tidak mengubah pola relasi gender dalam membentuk keputusan dalam rumah tangga. Hal ini dapat dilihat dari ilustrasi kepesertaan KB. Perempuan penerima manfaat Program Keluarga Harapan enggan menggunakan alat kontrasepsi KB dengan alasan dilarang suami.
\end{abstract}

Kata Kunci: peran; perempuan; pengelolaan dana; Program Keluarga Harapan; perkotaan 


\section{Introduction}

The implementation of Family Hope Program, hereinafter referred to as Program Keluarga Harapan $(\mathrm{PKH})$, puts women as the object of receiving and managing funds without a full role (Puspitawati 2010). The phenomenon of women's inability to manage PKH funds even occur in urban areas. There are still many forms of unequal gender relations experienced by many women in urban areas (Rahminawati 2001; Susanti 2007). One area in Surabaya with high alocation of PKH funds is located in Sidotopo Jaya RW 12 (Setijaningrum 2013). This densely populated area has a poor community with low access to education and become the government's pilot project of Family Planning village due to high birth rates (Khotimah et al. 2019). Unlike other studies with focus on PKH's implementation in rural areas, this research examined the implementation of this conditional cash transfer program in one of big cities in Indonesia. This study becomes interesting because it was carried out during the East Java governor election campaign as well as discourse in adding the amount of funds and number of beneficiary families of PKH in East Java.

Although PKH is still reaping various polemics in its implementation (Dehani et al. 2018), this program has been responded positively by the Ministry of Social Affairs by increasing the number of recipients in various regions, including East Java to 400 thousand recipients in 2018. The increased reached 435,334 from the original of 1,077,294 beneficiary families, thus the total of beneficiary family in 2019 was 1,512,628. This will simultaneously increase the amount of PKH budget for the Ministry of Social Affairs that reaches around Rp 400 billion, specifically for East Java. Surabaya is one of the cities receiving PKH assistance with high allocation in 2017. Overall social assistance reached Rp 145 billion, with details of $\mathrm{PKH}$ assistance for 24,043 families valued at Rp $45,441,270,000$, non-cash food assistance for 72,590 families worth IDR 99,564,444,000, as well as domestic grant assistance for 2,015 families worth $\mathrm{Rp} \mathrm{406,000,000.}$

The conditions set out in this program are interventions to address the issues of welfare and gender disparities in daily life. Thus, the target of PKH is an adult woman or mother (grandmother, aunt, or sister) who is commonly called the family caretaker (Suntiana et al. 2015). The purpose of giving it to family administrators is believed to be able to encourage the effectiveness of this program in improving the quality of education and health of beneficiaries (Purwanto et al. 2013; Kholif 2014; Yuwinanto 2018).

The increasing number of beneficiary families of PKH is unfortunately not accompanied by women's equality in the household. In fact, it is quite clear that women are important subjects in fund management in the household (Ariadi \& Sudarso 2018). This study aimed to identify the role of women in the use and management of PKH fund and describe the process of gender relations formed in the beneficiary families of PKH in Surabaya.

Several studies examining women receiving PKH fund have been carried out. Hatta \& Sarkawi (2011) in his study entitled "The Poverty Situation in Indonesia: Challenges and Progress of the Marginalized Group" in 2011 tried to describe how poverty alleviation programs in Indonesia work with existing procedures. The two programs discussed in the study were unconditional cash transfer program (ICT) and PKH. The ICT program, which was conducted in Indonesia in 2005, made the income of underprivileged families increased by 1.3 -fold compared to non-recipients. Moreover, Zulkarnain found that PKH, which was piloted in 2007, provided access to new resources for women and became the basis for developing a social security system for the future of women.

Sirojudin Arif et al. in their study entitled "Are conditions pro-women? A case study of conditional cash transfers in Indonesia" examined the impact of PKH on gender relations in the household. The study sought to reveal how local culture and norms interact with PKH at the household and community level and how the cultural relations and local norms that interacted with PKH could influence the results of the program. Sirojudin et al. employed a qualitative research methodology conducted in four villages under two different cultural backgrounds in West Java and East Nusa Tenggara. The study found that after two years of implementation, PKH did not affect gender relations 
in the household or woman's position in the household. In addition, husband's involvement is very important in PKH because of the dominant role played in decision-making related to children's education and health assistance for children.

The Family Hope Program implemented in Indonesia is a program that emulates some countries that have successfully implemented it first, such as Brazil and Mexico (Nazara \& Rahayu 2013; Kwon \& Kim 2015). However, in its development, many developing countries finally adopted the program and tried to implement it in their countries. Some studies examining programs that are internationally famous for conditional cash transfers (CCT) include Alan De Brauw in 2014 with the title of" The Impact of Bolsa Famı'lia on Women's Decision-Making Power." Bolsa Familia is similar to PKH program in Indonesia. This research focused on how women have room to increase their strength in household decision making that receive the Bolsa Familia program. This research employed a qualitative methodology. This study found that the Brazilian Bolsa Familia program has a significant impact on women's decision making, but with considerable heterogeneity in its effect. Bolsa Famulia significantly increased the power of women's decision making regarding contraception. The program's implementation in urban areas also significantly increased the power of women's decision making in areas related to school attendance, children's health costs, household durable goods purchases, and contraceptive use. Meanwhile, when the Bolsa Familia program was introduced to rural households, a quite striking difference occurred as there was no change, increase and possibility to reduce the power of women's decision making.

Not only in Brazil, conditional cash transfers (CCT) program also occur in other countries in the Americas, such as Mexico and Nicaragua (Adato \& Hoddinott 2010; Calvo 2011). Recent research conducted by $\mathrm{C}$. Radel with the title of "The gender dynamics of conditional cash transfers and small holder farming in Calakmul, Mexico" in 2016 focused on how the CCT program in poverty affected the production and dynamics of gender in the agricultural sector, especially farmers little girl. This qualitative study found that the beneficiary families of CCT were more likely to be involved in the cultivation of semi-subsistence corn and average harvest for more corn. Women who received direct cash assistance were more likely to hold land rights and share in income receipts from the four main crops. Therefore, with this direct cash assistance program, women actively produced agricultural sector, especially corn farming in Calakmul.

Subsequent research took place in Nicaragua in 2008 and 2013. In 2008, a research conducted by Seth R. Gitter \& Bradford L. Barham with the title of "Women Power, Conditional Cash Transfers, and Schooling in Nicaragua" focused on three important points of women strength, conditional cash transfers, and schools in Nicaragua. The term of Conditional Cash Transfers in Nicaragua is called Red de Protección Social (RPS). RPS is one of many conditional cash transfer programs that pay household cash benefits in exchange for school attendance and regular visits to health clinics by children. The main purpose of this program is that the payment is made to the female head of household. Previous research has shown that programs given to women are more likely to be spent on the health, nutrition, and education of their children. This research methodology used a qualitative approach with random experimental data from RPS. The RPS data were used to test the impact of heterogeneous programs on school enrollment and learning based on women's strength. The results of this study indicated that the RPS program had a significant impact on women's strength as well as increasing food and education expenditure. However, with the strength of women that exceeded the strength of her husband, it made children's school enrollment decreased.

On the other hand, Pamela J. Neuman conducted a study entitled "The Gendered Burden of Development in Nicaragua" with focus on the impact of conditional cash transfers (CCT) in Nicaragua on rural women and how the program affected the structure of women in rural areas of Nicaragua. The ethnography study found that the program increased women's daily workload. The CCT program also strengthened neoliberal ideals about self-efficacy in women's daily lives, contributing to rural poverty. However, despite many positive impacts on women resulting from this program, women did not change much the structural conditions that affected women's survival in rural Nicaragua. 
The two studies set in Nicaragua were both focused on the aspect of women in terms of managing conditional cash transfers. Although the results were different due to different settings, the results of the latest studies showed a declining condition of women. In addition, it could be inferred that the Red de Protección Social suffered a setback in 2013.

Unlike other previous studies, this research examined gender relations occured in urban areas even though CCT program has been implemented for a very long time in Indonesia. Generally, some previous studies took place in rural areas due to the linkages of CCT program and poverty problems. In addition, the setting of this study was conducted in Surabaya, which incidentally is the second largest city after Jakarta.

\section{Research Methods}

This study employed a qualitative approach. According to Neuman, one of the characteristics of qualitative research is to be descriptive, in which the researcher is more dominant in accommodating data in form of words, pictures, descriptions, from the results of informants rather than numbers (Neuman 2016).

This study was carried out in a poor community area on the outskirts of Surabaya, namely Sidotopo Subdistrict of Semampir District. Sidotopo Jaya RW 12 is an area that is classified as slums and densely populated. In addition to a fairly heterogeneous society, the community in this area has a low access to education, lack of awareness of environmental cleanliness, with large number of urbanites arriving. In addition, Sidotopo Jaya RW 12 is the only area in Surabaya that was chosen by the city government as a pilot project for the Family Planning village due to low participation of mothers in participating in the family planning program followed by high birth rates. In fact, the area received a quite high allocation of PKH in Surabaya.

Informants in this study were chosen using snowball sampling, in which the subject was chosen through a rolling process from one respondent to another respondent. The first step was meeting staff of Semampir District office to obtain information about beneficiary families of PKH in Sidotopo Jaya RW 12. The researcher then chose group leader of PKH in RW 12. The group leader was considered able to provide as much information as needed during the research process. The group leader then gave information about members of the group that were used as the next informant and so on until reached this study's qualification. The subjects in this study were beneficiary families of PKH, while the informants were beneficiary families, namely adult women or mothers (grandmothers, aunts or older sisters) who were usually called family administrators and received the fund.

The first step in data analysis was transcribing the results of the interview. After transcribing the interview results, the researcher reread and checked the transcript results. The step followed by finding key words in form of informant's utterances and gestures needed to answer the research focus. After finding key words in the transcript, the researcher then carried out an analysis and provided a detailed and accurate picture of the observations and interviews in the field. After analyzing with the right theory to describe the process of gender relations and the role of women in managing PKH fund, the researcher interpreted the theory to produce propositions used to assist and direct the process of drawing conclusions.

\section{Results and Discussion}

\section{Implementation of Family Hope Program in urban area}

Welfare issues occured in suburban areas such as Sidotopo Jaya RW 12 still become a homework for policy makers. Various problems such as high birth rates, increased dropout rates, as well as slums and unclean areas lead to health problems that cannot be neglected. Based on the data obtained, the total population in Sidotopo Jaya RW 12 is 2,592 people, consisting of 1,270 men and 1,320 women. Of 
this number, the population group with an age range of 15 to 24 years was 332 people, 25 to 49 years was 793 people. Judging from the available data, the productive age in the area is quite high compared to other age categories. This is considered as a potential that can provide opportunities to empower and prosper the community in Sidotopo Jaya RW 12. Nearly 79\% of women in this area chose to have early marriage under the age of 20 because of limited access to education and economy. In addition, patriarchal culture which is quite strong and inherent in Sidotopo society is believed to still dominate. Some women get married for family economic reasons. Daughters become a burden on the family if they are not immediately married.

The recipient of PKH funds in this area is quite high, 880 residents compared to other subdistrict in Surabaya. The amount of funds received is Rp. 500,000 (five hundred thousand rupiah) per three months. The number of children owned by each family is different, even nearly 400 young couples in this area are reluctant to join a family planning program. Therefore, a family can have more than two children. This condition was explained by the leader of Sidotopo Jaya RW 12 who stated that his area was the most productive.

Sidotopo is an area that is classified as slums and densely populated. In addition to a fairly heterogeneous community, the community in this area has low access to education, lack of awareness of environmental cleanliness, with large number of urban residents. Because population control in this region is quite vulnerable due to early marriage at productive age, Sidotopo Jaya has become a pilot project area for Family Planning Village program. This on-going program, however, has no tangible and sustainable efforts made by the government (Aji 2019).

\section{Activities of women benefiting Family Hope Program fund}

The beneficiary families of PKH are asked by the Ministry of Social Affairs to start moving into an independent community. Thus, the family is not only limited to a community group that always receives assistance from the government. However, in its implementation, misuse of PKH program is still commonly found in several areas, including urban areas. This deviation can be in the form of use that is not on target, and fund management that is not carried out by women but men as a determinant of allocation.

If the seeds of deviation are not addressed as early as possible, then any fund grants will be in vain. Thus, interaction between female members of beneficiary families needs to be encouraged and intensified so that the socialization of fundraising can be controlled. So far, the activities carried out by mothers in Sidotopo Jaya RW 12 have only been gathering and PKK activities. Thus, the intensity of meeting by members is limited. The meeting is only held when the funds will be disbursed. Moreover, supporting activities so that women can discuss and manage funds for empowerment have not yet occurred. In addition to women's business in urban areas who partly work in the industrial area, weak solidarity makes women in Sidotopo Jaya RW 12 ignore surrounding problems. Therefore, interaction between women is less intensive.

\section{Women as subjects benefiting from Hope Family Program fund}

Foucault is a theorist who explains when there is a relationship, that is power. One form of power relations is relation of domination. It is an asymmetric power relation where the subordinated subject has limited space to maneuver and limitations on the choice of action (Foucault 1982). During this time, if power is interpreted as originating from one epicenter, Foucault assumed that power occurs in all lines of life. Foucault illustrated that power is actually not centralized. Power is everywhere, not because power encompasses everything, but because power comes from everywhere.

In this case, power is not explained as the power that exists in a country or social institution and not also from something related to social structure. Power is actually a complex situation-strategy in people's lives. In his book entitled "Sexuality," Foucault argued that mastery over women originally came from the mastery of men over women's bodies. Through sufficient knowledge about sexuality, 
people will use greater power in their own lives. According to Foucault, sexuality is a particularly solid point of transfer for power relations. Foucault viewed the goal he wanted to achieve regarding the relations of power and sexuality is to define the regime of power-knowledge-pleasure that sustains the discourse about human sexuality in part of our world.

The power of sexuality does not reside in one main source sphere, the power is in various micro settings. Power over life takes two forms, namely: (1) There is a "political-anatomical human body", which in its goal is to discipline the human body and its sexuality. (2) There is also a "bio-political population" in which the object is to control and regulate population growth, health, life expectancy and so on. The position of women in this study placed women as subordinate positions while men were in superordinate positions in managing the Family Hope Program funds.

Some previous studies showed that women are the subject of benefiting from PKH funds because this program has specific goals for women. This goal is clearly outlined in the 2016 Family Hope Program general manual. On the PKH participant's card, for example, it is clear that the recipient's name is written as the woman receiving the assistance, not a male / household head (Linjamsos 2013). The person who must and has the right to withdraw funds is the person whose name is listed on the Family Hope Program card.

There are two main objectives of the Family Hope Program that can be identified. First, as a conditional cash transfer (CCT), PKH is a form of direct, periodic and predictable cash payments to help poor families increase income. Nearly all countries that provide CCT program try to prevent negative effects caused by economic pressures arising from changes in policies and economic dynamics, both occurring domestically and from the effects of global flows. It is hoped that CCT can be useful to maintain standard living of every household, encourage the promotion of wealth creation, and minimize the effects of social pressure. Second, the role of women in the realm of decision making can be overcome by women without depending on the position of men (Galiani \& McEwan 2013; Cahyadi et al. 2018).

The Family Hope Program in Indonesia seriously places women as important subjects in its management in the household (Arif et al. 2011). This program is designed not only to ensure that the standard living of very poor household families is maintained despite economic shock, but are also expected to provide more free space for the role of women in the household economy (Hutagalung et al. 2009). The program aims to provide more free space for the role of women in improving welfare of their households. This is built on the assumption that women become the most vulnerable social groups in the midst of economic pressure and shock because of their traditional position in gender relations. This is supported by the reason that women can manage household finances, so that the quality of health and education of recipients can be improved (Syukri et al. 2010).

Based on the results of previous research, PKH puts the position of women equal to men. However, this program is targeting very poor households which incidentally holds a fairly strong patriarchal system. Women, who are benefiting form PKH program in urban areas, especially in Surabaya, are generally financially independent or become partners in earning a living for their families while at the same time bearing domestic burdens. Although most beneficiaries of the funds are women who are productive in economic terms, this study found that men still dominate strategic roles to regulate the allocation of funds received from the program such as phone credit.

\section{Unequal gender relations in the households}

One of the goals of PKH program that wants equality for women is difficult to realize. Even though this program has been initiated since 2007, gender relations in making household decisions are still dominated by men who act as husbands. Women tend not to dare to argue when confronted with issues that require joint decisions (Mather 1983; Spierings 2015). Women do not have autonomy over their own bodies (Clark et al. 1991; Ahl 2004). Therefore, women's reproductive rights in this case experience inequality (Kalev \& Deutsch 2018). Arif Budiman explained that women became 
dependent on men not only economically, but also psychologically. Many women believe that marriage is their only place to save their lives, because marriage can solve their economic and psychological dependency problems. This is indeed a natural result of such a social situation (Budiman 1985). Helpless woman rejects the desire of her husband to increase the number of children. Thus, the role of women is considered not to influence the number of children.

\section{Conclusion}

There are two main objectives of Family Hope Program. First, as a conditional cash transfer (CCT), the program is a form of direct, periodic and predictable cash payments to help poor families increase income. Through CCT, nearly all countries that provide the program try to prevent negative effects caused by economic pressures arising from changes in policies and economic dynamics, both occurring domestically and from the effects of global flows. It is hoped that CCT can be useful to maintain standard living of every household, encourage the promotion of wealth creation, and minimize the effects of social pressure. Second, the role of women in the realm of decision making can be overcome by women without depending on their position on men.

The role of women in managing PKH funds in Surabaya remains stagnant. Women benefiting from the funds also play a dual role. In addition to having role in formal and informal sectors, women carry out domestic functions such as caring for babies, cooking, and etc. These women do not carry out their proper role in managing finances, planning needs and spending. This indicates that men still dominate the role of determining household allocation, whereas women are only executors. In addition, PKH still cannot change structure of the existing gender relations within Surabaya community. The program also does not change pattern of gender relations in forming household decisions. This can be seen from the illustration of family planning participation. Women benefiting from PKH are reluctant to use family planning contraception due to husband's prohibition.

\section{References}

Adato M \& Hoddinott J (2010) Conditional Cash Transfers In Latin America. Baltimore: International Food Policy Research Institute.

Ahl H (2004) The Scientific Reproduction of Gender Inequality: A Discourse Analysis of Research Texts on Womens Entrepreneurship. Stockholm: Liber.

Aji MS (2019) Implementasi Program Kampung Keluarga Berencana dalam Upaya Peningkatan Efektivitas Program Keluarga Berencana (Studi Pada Kampung KB RW 12 Sidotopo, Kelurahan Sidotopo, Kecamatan Semampir, Surabaya). Thesis: Universitas Airlangga.

Ariadi S \& Sudarso (2018) Pengembangan Badan Usaha Milik Desa (BUMDes) di Jawa Timur. Jurnal Sosiologi Dialektika 13 (2): 169-182.

Arif S, Syukri M, Isdijoso W, Rosfadhila M \& Soelaksono B (2011) Are conditions pro-women? A case study of a conditional cash transfer in Indonesia. Center for Social Protection Research Report 3:37-66.

Budiman A (1985) Pembagian Seks Secara Seksual. Jakarta: PT. Gramedia Jakarta.

Cahyadi N, Hanna R, Olken BA, Prima RA, Satriawan E \& Syamsulhakim E (2018) Cumulative impacts of conditional cash transfer programs: Experimental evidence from Indonesia. National Bureau of Economic Research.

Calvo C (2011) Social work and conditional cash transfers in Latin America. Journal of Sociology and Social Welfare 38:53.

Clark R, Ramsbey TW \& Adler ES (1991) Culture, gender, and labor force participation: A crossnational study. Gender and Society:47-66.

De Brauw A, Gilligan DO, Hoddinott J \& Roy S (2014) The impact of Bolsa Família on women's decision-making power. World Development 59:487-504.

Dehani M, Hernawan D, \& Purnamasari I (2018) Evaluasi Program Keluarga Harapan (FHP) di Kecamatan Bogor Selatan Kota Bogor. Jurnal Governansi 4 (1):45-56.

Galiani S \& McEwan PJ (2013) The heterogeneous impact of conditional cash transfers. Journal of Public Economics 103:85-96. 
Gitter SR \& Barham BL (2008) Women's power, conditional cash transfers, and schooling in Nicaragua. The World Bank Economic Review 22 (2):271-290.

Hatta ZA \& Sarkawi DT (2011) The Poverty situation in Indonesia: Challenges and progress of the marginalized group. Asian Social Work and Policy Review 5 (2):92-106.

Hutagalung SA, Sirojuddin A \& Widjajanti I (2009) Problems and challenges for the Indonesian Conditional Cash Transfer Programme-Program Keluarga Harapan (FHP), SPA Working Paper 04, May 2009, Brighton: IDS.

Kalev A \& Deutsch G (2018) Gender inequality and workplace organizations: Understanding reproduction and change. In Handbook of the Sociology of Gender (pp. 257-269). Springer, Cham.

Kholif KI (2014) Implementasi Program Keluarga Harapan (FHP) dalam menanggulangi kemiskinan di Kecamatan Dawarblandong Kabupaten Mojokerto. Jurnal Administrasi Publik 2 (4):709-714.

Khotimah K, Ratnasari V \& Ratna M (2019) Pengelompokan kelurahan di Kota Surabaya berdasarkan kriteria pembentukan Kampung Keluarga Berencana. Jurnal Sains dan Seni ITS 7 (2): 122-128.

Kwon HJ \& Kim WR (2015) The evolution of cash transfers in Indonesia: Policy transfer and national adaptation. Asia \& the Pacific Policy Studies 2 (2):425-440.

Linjamsos D (2013) Pedoman Umum Program Keluarga Harapan (FHP). Jakarta: Kementrian Sosial RI.

Mather CE (1983) Industrialization in the Tangerang Regency of West Java: Women workers and the Islamic patriarchy. Bulletin of Concerned Asian Scholars 15 (2):2-17.

Nazara S \& Rahayu SK (2013) Program Keluarga Harapan (FHP): Indonesian conditional cash transfer programme. International Policy Centre for Inclusive Growth.

Neuman WL (2016) Understanding Research. Pearson.

Purwanto SA, Sumartono S \& Makmur M (2013) Implementasi kebijakan Program Keluarga Harapan (FHP) dalam memutus rantai kemiskinan (Kajian di Kecamatan Mojosari Kabupaten Mojokerto). WACANA: Jurnal Sosial dan Humaniora 16 (2):79-96.

Puspitawati H (2010) Analisis structural equation modelling tentang relasi gender, tingkat stres, dan kualitas perkawinan pada keluarga penerima Program Keluarga Harapan (FHP). Yinyang: Jurnal Studi Islam Gender dan Anak 5 (2):328-345.

Radel C, Schmook B, Haenn N \& Green L (2017) The gender dynamics of conditional cash transfers and smallholder farming in Calakmul, Mexico. In Women's Studies International Forum 65:1727 Pergamon.

Rahminawati N (2001) Isu kesetaraan laki-laki dan perempuan (bias gender). Mimbar: Jurnal Sosial dan Pembangunan 17 (3):273-283.

Setijaningrum E (2013) Desain Program Terpadu Penanggulangan Kemiskinan di Perkotaan. Surabaya: Airlangga University Press.

Spierings N (2014) The influence of patriarchal norms, institutions, and household composition on women's employment in twenty-eight Muslim-majority countries. Feminist Economics 20 (4):87-112.

Suntiana L, Kanto S \& Soenyono S (2015) Rancangan model kebijakan penanggulangan kemiskinan dalam perspektif pemberdayaan perempuan (Kajian terhadap implementasi Program Keluarga Harapan di Kecamatan Sumberbaru Kabupaten Jember). WACANA: Jurnal Sosial dan Humaniora 18 (3).

Susanti E (2007) Ketimpangan Gender dan Ketidakberdayaan Perempuan Miskin Perkotaan. Surabaya: Insan Cendekia.

Syukri M, Sirojuddin A, Meuthia R \& Widjajanti I (2010) Making the best of all resources: How Indonesian household recipients use the CCT allowance. IDS Bulletin 41 (4):84-94.

Yuwinanto HP (2018) Pelatihan keterampilan dan upaya pengembangan UMKM di Jawa Timur. Jurnal Sosiologi Dialektika 13 (1):79-87. 